\title{
ИстОРИЯ
}

DOI 10.17805/ggz.2017.4.3

\section{Трансформация ментальности римского гражданина в период складывания вертикали власти эпохи принципата}

\author{
Д. Е. ТОРОС, Л. И. КОЛЕСНИЧЕНКО
}

МОСКОВСКИЙ ГУМАНИТАРНЫЙ УНИВЕРСИТЕТ

Статья посвящена эволюции ментальности римского гражданина в период складывания вертикали власти в эпоху принципата, начинающуюся с Августа. Показаны исторические события, которые определяли эту ментальность. Статья подготовлена на основе доклада на Международной научной конференции «Культура в поисках будущего: человек - общество - природа» в Московском гуманитарном университете (30-31 мая 2017 г.).

Ключевые слова: история Древнего Рима; принципат; ментальность; римский гражданин

\section{Transformation of the Mentality of the Roman Citizen in the Period of Formation of the Vertical of Power in the Era of the Principate \\ D. E. TOROS, L. I. KOLESNICHENKO \\ MOSCOW UNIVERSITY FOR THE HUMANITIES}

The article is devoted to the evolution of mentality of the Roman citizen in the period of development of the vertical of power in the age of the Principate, starting with Augustus. The authors describe the historical events that defined this mentality. The article is prepared on the basis of the report presented at the International conference "Culture in Search of the Future: Man - Society - Nature", Moscow University for Humanities (May 30-31, 2017). Keywords: history of Ancient Rome; Principate; mentality; Roman citizen

Современный человек европейско-американской цивилизации до сих пор пользуется культурным наследием Аревнего Рима - институтами государственной власти, системой и терминологией Римского права, стратегией и тактикой военного дела, смыслами и понятиями литературы «золотой латыни», памятниками искусства и другими достижениями древности, приспосабливая это наследие в рамках экологии куль- туры к своим целям.

Именно в Риме сложилась политическая система, которую нельзя встретить ни в одном другом государстве мира - принципат как уникальная переходная политическая форма, которую нельзя отнести в чистом виде ни к республике, ни к империи. Официально провозглашенная реставрация республики в период правления Августа обернулась установлением режима наследственной монархии. Этот процесс затронул 
и общественное сознание. Эпоха принципата - самый противоречивый период древнеримской истории, наполненный многочисленными событиями: от великих побед до больших несчастий. Это период исторически определил последующее развитие Римской империи.

Ментальность римлянина подверглась жесткой фрустрации. Идеологическое обеспечение формирующегося нового режима требовало изощренной политической пропаганды.

Римская империя была самой крупной территориальной и могущественной в военном отношении мировой державой (Крист, 1997). Она являлась воплощением наивысших достижений цивилизации и культуры древнего мира, и распространяла свои духовные и материальные завоевания на все народы, входившие в ее состав: романизированные Средиземноморье, Мессопотамия, Ассирия, Британия, Армения, Аакия, Аравия и Германия в период принципата стали общей родиной для всех народов, оставив нам в наследство естественно-технические знания эпохи, шедевры культуры, литературы и искусства.

Римской империей тогда правили выдающиеся государи. Большинство из них были яркими индивидуальностями. Благодарная память потомков сохранила имена умных правителей, дальновидных администраторов, дипломатов и воинов, заботившихся о благе государства и его народов. Таковыми были императоры Август, Веспасиан, Тит. Некоторые остались в истории тиранами и злодеями. Аостаточно назвать имена Тиберия и Калигулы, Нерона и Аомициана (Федорова, 1998; Петряков, 2012).

Римские историки дают различную оценку событиям периода становления принципата. После победы в гражданской войне Август объявил о восстановлении прежнего, республиканского порядка, и соответствующий ему культурной политики. Веллей Патеркул в «Римской истории» так восхищался решениями принятыми Августом: «...восстановлен мир, повсеместно усыплен страх перед оружием, законам возвращена сила, судам - их авторитет, сенату - величие, магистратам - власть и старинный порядок полномочий (только лишь к восьми преторам добавлены еще два...)» (Веллей Патеркул, 1996: 342). Патеркул восторгался тем, что Август отверг диктатуру и звание триумвира, называя себя лишь принципсом, то есть первым в списке сената, был консулом одиннадцать раз и занимал должность народного трибуна. Но Август «...начал подменять собою сенат, магистратов и законы, пересмотрел списки сената и значительно их сократил, исключив всех неугодных ему лиц» (Гай Светоний Транквилл, 2015: 81). С это момента сенатором мог быть только тот, чье состояние достигало одного миллиона двухсот тысяч сестерциев (там же: 9). Таким образом, был введен имущественный ценз. Корнелий Тацит подчеркивает: «...основы государственного порядка претерпели глубокое изменение, и от общественных изменений старого времени нигде ничего не осталось. Забыв о недавнем равенстве, все наперебой ловили приказания принцепса» (Корнелий Тацит, 1993: 4). Налицо переформатирование системы управления в период принципата, что определило его двойственный характер при сохраненных республиканских органах управления, все подчинялось решению одного человека - принцепса. Позже это привело к тому, что многие принцепсы превращались в тиранов и заканчивали свою жизнь насильственным путем, в результате заговора. После убийства Калигулы, сенат сделал попытку восстановить республиканский строй, но время было упущено. Сторонники восстановления аристократической республики не получили поддержки среди воинов, римского плебса и провинциальной рабовладельческой аристократии (Гарай, 2012). 
Переход управления государством к принцепсу произошел благодаря наделению его высшей властью сенатом, избранию на важнейшие должности, созданию им отдельного от магистратур чиновничьего аппарата, образованием собственной казны принцепса, и командованию всеми армиями.

Вместе с тем, надо отдать должное одаренности и личным усилиям Августа в этой кропотливой работе. На протяжении своей жизни Август занимался помимо государственной политической деятельности дитературным творчеством - был плодовитым писателем и сочинителем на философские темы. Его воспоминания «О своей жизни» - громадный труд в 13 книгах, содержит описание событий, приведших Августа к власти, с точки зрения его самого и с теми оценками, которые он хотел закрепить в сознании современников и в памяти последующих поколений (Шифман, 1990). Имели также хождения и письма Августа. Император упражнялся и в поэзии. Ему принадлежали поэма «Сицилия» и сборник эпиграмм. В них нетрудно разглядеть прямой выпад против Антония, который обвинял Августа во всевозможных постыдных деяниях. Эти сочинения остроумные современники назвали «резвой литературой». Налицо политическая перебранка, но она не страшна принцепсам. Во время правления Августа создавались публичные библиотеки и устраивались общественные чтения новых литературных произведений с предполагаемым господствующим духом в них. В этом принимали участие Вергилий, Гораций, Овидий, Асиний Поллион и другие.

Независимость и непримиримость вольномыслия поэтов провозглашалась опасной. В этом плане показательна судьба Овидия Публия Назона, члена поэтического кружка Мессалы, одного из троицы ведущих поэтов и писателей Августовского века (там же). Работы Овидия над «Метаморфозами» («Превращениями») и над «Фестами» («Календарь») не были завершены и прерваны изгнанием, отнюдь не за фривольность содержания. Возможно, Август в них отследил помимо официального прославления язвительный подтекст перевоплощения из республиканца в тайного узурпатора. «Земной Юпитер» в творчестве Овидия не состоялся, и автор закончил свои дни в глубокой провинции. Поэт изображал нравы римского общества и противопоставлял их староримскому идеалу. Август и читатели и это хорошо поняли. Bсе, что не соответствовало создаваемой базе режима, подвергалось изъятию. И все же Август сумел превратить авторитетнейших писателей своего времени в рупор тех общественных идей, которые были нужны его режиму, и являясь его идеологическим фундаментом.

Октавиан Август получил «imperium», включавший помимо традиционного командования армией, право объявлять войну, заключать мир и международные договоры, содержать собственную гвардию (преторианские когорты), право высшего уголовного и гражданского суда, право толковать законы. К концу эпохи принципата общепризнанным станет положение: «Что решил принцепс, то имеет силу закона». Принцепсы стали избираться в нарушение республиканских традиций одновременно консулами, цензорами и народными трибунами. Как консул он мог, воспользовавшись правом интерцессии, отменить решение любого магистрата, как цензор - формировать сенат из своих сторонников, как трибун - наложить вето на постановление сената или решение магистрата. Он получил звание понтифика - верховного жреца, ведавшего отправлением религиозных культов.

Реставраторская политика Августа находила свое выражение и в религиозной сфере. Он получил звание понтифика - верховного жреца, ведавшего отправлением религиозных культов, демонстрировал негативное отношение к чужеземным суевери- 
ям. В особую заслугу Август ставит себе восстановление старых храмов и строительство новых, посвященных римским богам.

Первостепенное значение Август придавал внедрению в сознание римлян культа рода Юлиев, Юлия Цезаря и, разумеется, самого принцепса. Такую роль играл прежде всего культ Венеры Прародительницы, напоминавший о божественном (от Венеры) происхождении рода Юлиев (там же). В рамках реставрационной политики Августа находит свое объяснение и проведенное упорядочение римского юлианского календаря, когда он мимоходом одному из месяцев, секстилию, присвоил свое имя - Август (там же). Особое место занял в римской религии и культ Гения Августа. Он был включен в систему домашних богов, покровителей дома и очага. Август воспринимался как спаситель, основатель, освободитель и благодетель мира. Хотя сам Август стремился демонстрировать сдержанность и не разрешал строить себе отдельные храмы, позволял только соединение своего культа с давним культом богини Рима, существо дела, разумеется, от этого не менялось.

При Августе появился необходимый и зловещий феномен чиновничества, связанный с политическими реформами в управлении. Бывшие когда-то выборные почетные должности, назначаемые императором, стали оплачиваемыми. Вскоре рост должностей естественным образом привел к падению их значимости, народ был постепенно удален от управления государством. Причем видимость республиканского устройства сохранялась в риторике, император активно поддерживал ее традиции: «...присутствуя на выборах должностных лиц, он всякий раз обходил трибы со своими кандидатами и просил за них по старинному обычаю» (Гай Светоний Транквилл, 2015: 87).

Наряду с вышеперечисленными республиканскими магистратами развивался также императорский бюрократический аппарат, приобретавший все большее значение. Создавая этот аппарат, Август в первую очередь использовал личные связи, назначая лично людей для выполнения его поручений. Во вновь созданный императорский чиновничий аппарат, на вершине которого стояли совет и канцелярия принцепса, входили несколько ведомств со штатом чиновников. В совет были включены префекты, «друзья» императора, начальники ведомств канцелярии. В канцелярию входили ведомства финансов, прошений, официальной переписки, личного имущества императора, императорского суда и др. Члены совета, выполнявшего совещательные функции, и начальники ведомств канцелярии назначались самим принцепсом из его приближенных. Ими часто становились вольноотпущенники или лица, не являвшиеся гражданами Рима, однако на высшие должности назначались выходцы из первых сословий. Компетенция сената существенно изменились, поскольку из народных собраний сохранились только трибунные, созывавшиеся к тому же все реже. С I в. постановления сената - сенатус-консульты получают силу закона. Но право принцепса назначать сенаторов и периодически проводившиеся принцепсами «чистки» сената приводили к тому, что со II в. сенат практически только утверждал предложения принцепса. Почти тоже произошло с перешедшим от народного собрания к сенату правом избирать и контролировать магистратов. Часть из них могла быть избрана только из кандидатов, предложенных принцепсом. Ограничиваются права сената по распоряжению государственными финансами и управлению провинциями. Полностью утрачивается его компетенция в военной и внешнеполитической областях.

Произошли изменения и в судебной системе. Был принят Цинциев закон «О подарках и воздаяниях», в котором говорилось, что подсудимые не должны платить за защиту в суде «сверх меры», что является официальным подтверждением превраще- 
ния процесса защиты из почетной обязанности патрона в профессиональное дело адвокатов. Аля большей части населения римской империи это стало неподъемным бременем и сделало их беззащитными перед судебной системой. Судей назначали на определенный срок, но некоторые категории граждан имели освобождение от назначения на должности. Например, у Тацита мы можем прочитать упоминание о злоупотреблениях судебной властью в период правления Клавдия, который «потакал произволу немногих могущественных» (Корнелий Тацит, 1993: 60). В правление же Нерона судом управлял сенат, а Нерон занимался делами провинций, в которых было военное управление. У Светония можно найти упоминание, что Гай Калигула хотел отменить науку правоведов «чтобы никакое толкование законов не перечило его воле» (Гай Светоний Танквилл, 2015: 198). Принцепс стал верховным судьей империи. Из «Закона об империуме Веспасиана» мы видим, что принцепсы могли заключать союзы, созывать сенат, вносить предложения для рассмотрения и брать их обратно, поручали магистратам надзор за каким-либо делом.

Провинциями Римской империи управлялись наместниками - администраторами сенатского или всаднического ранга, которые несли службу постоянно, и если им требовалось уладить свои дела, они должны были получить разрешение императора. Подтверждение этому мы можем видеть в переписке императора Траяна с Плинием Младшим, который был наместником в Вифинии (Гай Плиний Младший, 1984). По спорным вопросам, делам требующим больших затрат, наместники должны были спрашивать согласие императора, а в текущих делах могли принимать самостоятельные решения. Так они вели судопроизводство по тяжким уголовным преступлениям и разрешали споры, возникающие между общинами. Но управление провинциями еще опиралось на систему местного управления.

Как видно из речи императора Клавдия в сенате о допуске в сенат знатных галлов, римские патриции не хотели допускать в сенат провинциалов из Нарбоннской Галлии. И только настояние Клавдия решило вопрос положительно. В сатире на смерть императора Клавдия, Сенека весьма саркастически, описал «желание Клавдия предоставить гражданство Рима некоторым провинциям. "Клото” хотела ему малость надбавить веку, чтобы успел он и остальным, которые все наперечет, пожаловать гражданство. (А он ведь решил увидеть в тогах всех - и греков, и галлов, и испанцев, и британцев)» (Ауцций Анней Сенека, 1891: 53).

Оплотом правителей Римской империи в их внутренней и внешней политике являлась надежная и преданная принцепсу армия. С момента кризиса республиканской власти армия становится решающей силой в политической жизни страны. Переход к империи непосредственно выразился в том, что профессиональная армия, перешла в подчинение одного человека, их главнокомандующего, который получил возможность проводить свою политику. На эту силу опирались все ее претенденты. «Август... сначала покорил своими щедротами воинов, раздачами хлеба - толпу и всех вместе - сладостными благами мира...» (Корнелий Тацит, 1993: 4). И только при поддержке армии и плебса Август смог прийти к власти. Это давало армии понимание того, какую роль она играет в политической жизни страны. Поддержка армии являлась определяющим фактором смены императоров. Впоследствии, когда Нерон своими злодействами и безобразиями истощил терпение римлян, и против него восстали войска, находившиеся в Галлии, Испании и Африке, а в Риме - преторианцы, армия сыграла решающую роль - Нерон оказался первым императором, при жизни лишенным власти (Гай Светоний Транквиля, 2015). 
Многие правители, добиваясь популярности в армии, устраивали раздачу денежных подарков и земли. На монетах чеканились сцены прибытия императора на театр военных действий, триумфальные возвращения армии, сцены выступления перед войсками, участие в маневрах армии, походах. Аля завоевания авторитета и поддержания настроения в армии чеканились монеты, выпущенные в честь отдельных легионов, иногда преторианской гвардии. Можно утверждать, что раздача монет с соответствующими легендами, стала почетной акцией, способствующей моральному, политическому единению лидера со своими войсками (Гиро, 2002). А это явление уже из области политической пропаганды. Факты присяги легионеров императору отмечались специальными выпусками монет с изображением соответствующих сцен с участием императора и войска. Со времени Августа, большую роль играли основания многочисленных провинциальных колоний ветеранов. Эти колонии получали землю и иногда их наделяли, так называемым, «италийским правом». Эти колонии стали форпостами последующей романизации земель (там же).

Аальнейшие события истории в Римской империи в период принципата показывают, что вожди легионеров имели больше всех шансов стать императором. После смерти последнего представителя династии Юлиев-Клавдиев в стране начался разгул произвола. В июне 68 г. испанскими и галльскими легионами императором был провозглашен Гальба. Он отказался заплатить воинам за свое избрание, твердо заявив, что привык вербовать, а не покупать воинов (Гай Светоний Транквилл, 2015). Разъяренными преторианцами, желая получить деньги, его убили и провозгласили нового императора. Германские легионеры объявили своего императора. Как отмечает Гай Светоний Транквилл, «...воины уже привыкли создавать себе императоров на основании беспорядочного решения и легко сменять их..., а такое положение дел породило гражданские войны, во время которых воину, предназначенному для борьбы против врага, приходилось погибать в братоубийственной брани» (там же). В результате борьбы главой государства стал талантливый полководец Веспасиан, о котором римляне сохранили благодарную память, как об одном из результативных императоров. Таким образом, политическая система выстраивающегося принципата стала зависеть от руководства армии, что впоследствии приводило к многочисленным гражданским войнам.

Перечисленные события не могли не вызывать размывания ментальности римского гражданина. Гражданские качества нивелируются, а качества серва превалируют. Формируется спрос на управленца, способного к приспособленчеству и заискиванию. Растущая зависимость всех от воли вышестоящих, отсутствие общих целей и перспектив служения Отечеству, заменившихся лишь перспективой личного выдвижения, к тому же весьма неверного, поскольку любого могла ожидать опала или разорение по экономическим и другим причинам, усиливали чувство разобщенности и отчуждения граждан от сочувствия и поддержки государства. Они усугублялись тем обстоятельством, что «яркие индивидуальности» не поощрялись ни в своей среде, ни вышестоящими. У философов и литераторов мы постоянно встречаем жалобы на презрение и насмешки, советы не подавать к ним повода, не привлекая недоброжелательного внимания своим отличным от прочих видом и поведением (Гарай, 2012).

В результате не только исчезли большие, вдохновляющие, коллективные цели, но и стимулирующие деятельность цели личные стали существенно ограниченными. Жизнь каждого римского гражданина стала предопределяться его сословной и статусной принадлежностью, происхождением, местом рождения. В этих рамках она 
могла изменяться, улучшаться, но была регламентирована. Немалое значение имело и постепенное обветшание «римского мифа» и всех связанных с ним ценностей. Став темой повседневной пропаганды, эти ценности стирались, утрачивали эффективность воздействия. Если при Августе идея достигнутой Римом кульминации и выполнения его миссии была еще своевременной, связывалась с возлагавшимися на Августа большими надеждами, то теперь она стала привычной и никого не вдохновляла. Тоска завершенности, казавшейся навеки установившейся системы «вечного Рима» и «божественного», «непобедимого» императора, при всем видимом благополучии становилась все более гнетущей.

\section{СПИСОК АИТЕРАТУРЫ}

Веллей Патеркул. (1996) Римская история. М. : Аадомир. 388 с.

Гай Плиний Младший. (1984) Письма Плиния Младшего. М. : Наука. 565 с.

Гарай, Р. (2012) Римские императоры. Галерея всех правителей Римской империи с 31 года до н. э. до 476 года н. э. М. : Центрполиграф. 349 с.

Гиро, П. (2002) Частная и общественная жизнь римлян. Смоленск : Русич. 576 с.

Корнелий Тацит. (1993) Анналы. Малые произведения : Соч. : в 2 т. М. : Аадомир. Т. 1. 444 с.

Крист, К. (1997) История времен римских императоров от Августа до Константина. Ростовна-Аону : Феникс. 576 с.

Ауций Анней Сенека. (1891) Сатира на смерть императора. СПб. : Сытин. 119 с.

Петряков, А. (2012) Власть без предела. Калигула и Нерон. М. : О $\Lambda$ МА Медиа Групп. 512 с.

Светоний Гай Транквилл. (2015) Жизнь двенадцати цезарей. СПб. : Азбука, Азбука-Аттикус. $480 \mathrm{c}$.

Федорова, Е. В. (1998) Императорский Рим в лицах. Ростов-на-Аону : Феникс. 352 с.

Шифман, И. Ш. (1990) Цезарь Август. СПб. : Наука. 189 с.

Lата поступления: 20.06.2017 2.

Торос Ааниэль Евгеньевич - магистрант 2 курса кафедры философии, культурологии и политологии Московского гуманитарныого университета. Адрес: 111395, Россия, г. Москва, ул. Юности, 5. Тел.: +7 (499) 374-61-81. Эл. адреc: livkolesn@yandex.ru

Колесниченко Иариса Ивановна - кандидат исторических наук, доцент кафедры философии, культурологии и политологии, Московский гуманитарный университет. Адрес: 111395, Россия, г. Москва, ул. Юности, 5. Тел.: +7 (499) 374-61-81. Эл. адрес: livkolesn@yandex.ru

Toros Daniel Evgenievich, 2-year student, Department of Philosophy, Culturology and Politology, Moscow University for the Humanities. Postal address: 5, Yunosti St., Moscow, Russian Federation 111395. Tel.: +7 (499) 374-61-81. E-mail: livkolesn@yandex.ru

Kolesnichenko Larisa Ivanovna, Candidate of History, Asociate Professor, Department of Philosophy, Culturology and Politology, Moscow University for the Humanities. Postal address: 5, Yunosti St., Moscow, Russian Federation 111395. Tel.: +7 (499) 374-61-81. E-mail: livkolesn@yandex.ru

\section{Аля цитирования:}

Торос А. Е., Колесниченко $\Lambda$. И. Трансформация ментальности римского гражданина в период складывания вертикали власти эпохи принципата [Электронный ресурс]// Горизонты гуманитарного знания. 2017, № 4. URL: http://journals. mosgu.ru/ggz/article/view/556 (дата обращения: АА.мм.гггг.). DOI: 10.17805/ggz.2017.4.3 